\title{
PERCEIVED VALUE DAN PERCEIVED QUALITY TERHADAP BEHAVIORAL INTENTION WISATAWAN DI TAPLAU PADANG
}

\author{
Yuni Candra \\ Dosen Fakultas Ekonomi Universitas Tamansiswa Padang \\ Email: yuni.candra80@gmail.com \\ Hesti Mayasari \\ Dosen Fakultas Ekonomi Universitas Tamansiswa Padang \\ Email: hestimayasari27@gmail.com
}

\begin{abstract}
The purpose of this study was to determine the effect of perceived value and perceived quality partially to the behavioral intention of tourists in Taplau Padang. The population in this study are domestic tourists visiting Taplau Padang. The number of samples in this study were 30 respondents which using the technique of non probability sampling. This study is proving the perceived value and perceived quality can influence the behavioral intention of tourists. This study is using descriptive quantitative analysis method which statistical hypothesis testing. Stages of testing the authors do include multiple linear regression test, $t$-statistical test and coefficient of determination (R2). Results of multiple linear regression analysis in obtaining value $Y=5.255+0.751 X 1$ $+0.233 X 2+e$. Perceived value has a significant influence on the behavioral intention of tourists and perceived quality has no significant effect on the behavioral intention of tourists in Taplau Padang because the significant value is greater than 0.05. while simultaneously perceived value and perceived quality influence the behavioral intention of tourists in taplau Padang. And perceived value and perceived quality contribute to the influence of behavioral intention of $61.5 \%$ and the remaining $38.5 \%$ influenced by other factors.
\end{abstract}

Key word: perceived value, perceived quality dan behavioral intention

\section{PENDAHULUAN}

\subsection{Latar Belakang}

Kota Padang merupakan ibu kota Provinsi Sumatera Barat, mempunyai berbagai tempat objek wisata yang sering dikunjungi oleh wisatawan lokal, domestik maupun manca negara. Salah satu tempat wisata yang layak dikunjungi adalah pantai Padang atau sering juga disebut oleh masyarakat dengan disebutan Taplau (tepi lauik) Padang. Taplau Padang mempunyai pemandangan laut yang indah dan terletak dipusat kota Padang.

Taplau Padang, disamping memiliki keindahan laut, para wisatawan juga dapat dimanjakan dengan kuliner dan arena bermain. Fasilitas yang dimiliki berupa gazebo, trotoar, tempat parkir, tempat berdagang, tempat bermain anak, toilet, mushalla. Sarana penunjang lainnya yang tersedia berupa restoran, hotel, pujasera yang berada di sisi jalan sekitar pantai. Taplau Padang sendiri memiliki nama kecil di sepanjang Taplau tersebut, seperti, Pantai Muaro Lasak, Pantai Hangtuah, Pantai Cimpago dan Pantai 
Purus. Saat ini, Taplau Padang masuk ke dalam rencana strategis pembangunan Kota Padang.

Menurut visi dan misi Kota Padang tahun 2015 pada urutan No. 10 tentang Objek Wisata menjelaskan bahwa "Menjadikan pantai Padang sebagai salah satu wisata keluarga dan kovensi yang layak dan ramah bagi wisatawan, serta merevitalisasi objek wisata yang baik bagi wisatawan.

Kunjungan wisatawan ke Taplau Padang dapat dilihat dari jumlah wisatawan yang menginap di Hotel, terlihat pada gambar 1.1.

Gambar 1.1

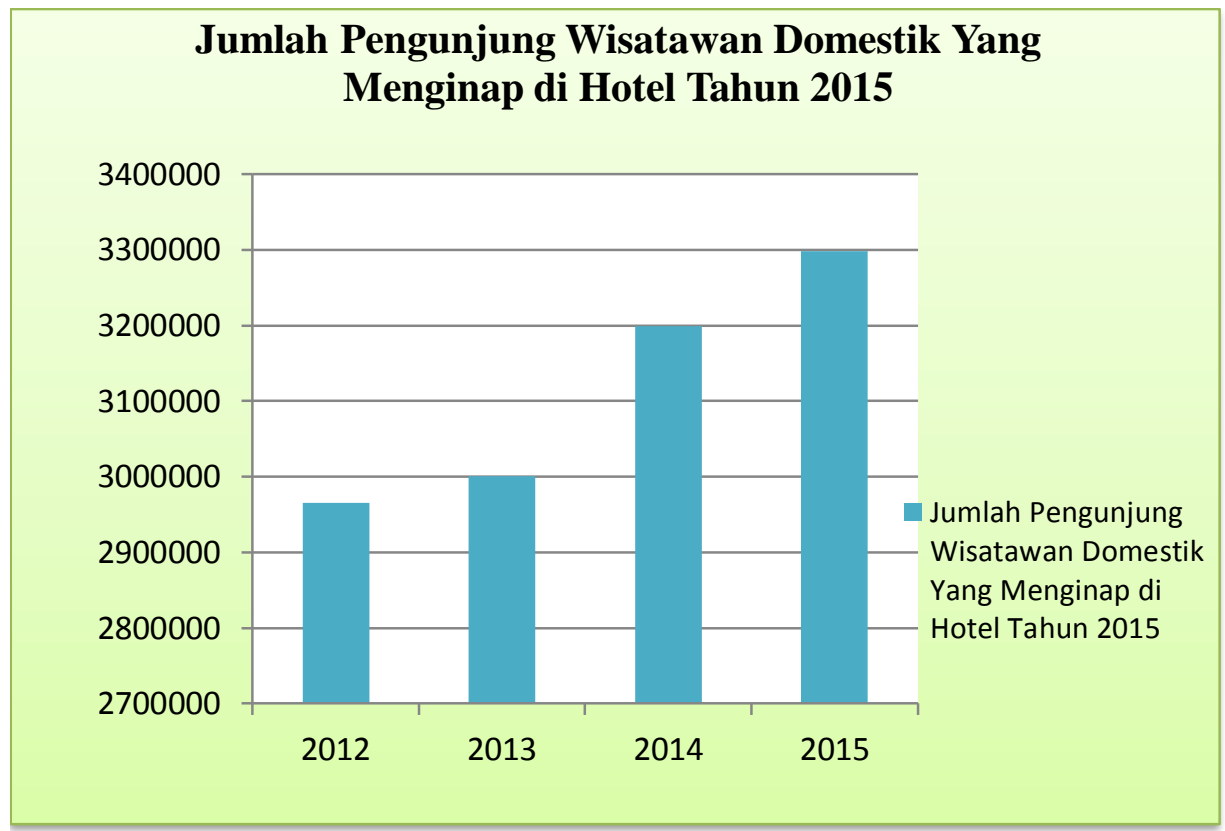

Sumber: Dinas Kebudayaan dan Pariwisata Padang 2016

Dari gambar 1.1 dapat dilihat bahwa jumlah pengunjung wisatawan domestik ke padang mengalami peningkatan dari tahun ke tahun, di tahun 2015 wisatawan domestik menginap di Hotel kota Padang berjumlah 3.298.454 wisatawan. Dalam hal ini, untuk menumbuhkan kembangkan tingkat wisatawan ke Kota Padang. Umumnya Taplau Padang, perlu pemahaman tentang perilaku konsumen, sebelum kegiatan promosi wisatawa dilakukan. Diketahuinya perilaku konsumen oleh pelaku wisata akan mempunyai pandangan tentang keinginan wisata, sehingga kebutuhan wisatawan dapat terpenuhi yang pada akhirnya dapat mendesain objek wisata sesuai dengan keinginan wisatawan.

Hal ini mengindikasikan bahwa kunjungan yang dilakukan oleh wisatawan ke Taplau Padang karena adanya nilai tertinggi yang ditawarkan (perceived value), dengan adanya nilai tersebut wisatawan akan mengevaluasi manfaat yang diterimanya dengan pengorbanan mereka untuk mendapatkan produk tersebut. Perceived value terhadap barang/jasa didasarkan pada kebutuhan (need), pengalaman (experiences), keinginan (desires), harapan (expectations), dan keyakinan (beliefs) mengenai barang/jasa tersebut. (bowman dan Ambrosini, 2000) dalam Suvi et al.

Secara umum industri jasa memiliki karakteristik yang berbeda dengan manufaktur, karena pada industri jasa produk yang dihasilkan tidak berwujud secara fisik. Karakteristik yang berbeda pada industri jasa seringkali menyebabkan pelanggan 
sulit untuk melakukan evaluasi terhadap kualitas sehingga ukuran kualitas sering mengacu pada persepsi pelanggan.

Disamping itu, wisatawan di Taplau Padang membtuhkan pelayanan yang baik diterimanya saat berkunjung ke Taplau Padang. Ada dua hal pokok yang berkaitan dengan layanan, yaitu harapan pelanggan terhadap kualitas langganan (expected quality) dan persepsi pelanggan atas kualitas layanan pada saat menerima layanan (experienced atau perceived quality). Pelanggan senantiasa menilai suatu layanan yang diterima dengan membandingkannya dengan apa yang diharapkan atau yang diinginkan. Pelanggan senantiasa menilai suatu layanan yang diterima dengan membandingkannya dengan apa yang diharapkan atau yang diinginkan, Subagio dan Saputra (2012).

\subsection{Rumusan Masalah} berikut:

Berdasarkan uraian latar belakang di atas maka permasalahan penelitian sebagai

1. Apakah perceived value berpengaruh terhadap behavioral intention wisatawan di Taplau padang?

2. Apakah perceived quality berpengaruh terhadap behavioral intention wisatawan di Taplau Padang?

3. Apakah perceived value dan perceived quality secara bersama terhadap behavioral intention wisatawan di Taplau Padang?

\subsection{Tujuan Penelitian}

Berdasarkan rumusan masalah di atas maka tujuan penelitian ini adalah:

1. Untuk mengetahui pengaruh perceived value terhadap behavioral intention wisatawan di Taplau Padang.

2. Untuk mengetahui pengaruh perceived quality terhadap behavioral intention wisatawan di Taplau Padang.

3. Untuk mengetahui pengaruh perceived value dan perceived quality secara bersama terhadap behavioral intention wisatawan di Taplau Padang.

\section{LANDASAN TEORI}

\subsection{Perceived Value}

Kotler dan Keller (2009:228), persepsi adalah proses yang digunakan oleh individu untuk memilih, mengorganisasi, dan menginterpretasi masukan informasi guna menciptakan gambaran dunia yang memiliki arti. Nilai pelanggan merupakan kombinasi kualitas, pelayanan, harga dari suatu penawaran produk.

Zeithaml dalam Ernawati dan Sriwidodo (2012), perceived value didefinisikan sebagai penilaian menyeluruh konsumen atas manfaat dari suatu produk atau jasa berdasarkan persepsi atas apa yang telah diberikan dan atas apa yang telah didapat. Chi (2011), Indikator perceived value adalah sebagai berikut : Nilai fungsional, Nilai emosional, Nilai sosial.

Peningkatan perceived value akan meningkatkan Behavioral Intention, atau penilaian penunjung pengunjung meningkat maka meningkatkan niat berperilaku di masa mendatang. Sehingga, persepsi nilai dianggap sebagai determinan penting dalam meningkatkan Behavioral Intention (Bajs, 2013; C.-F. Chen \& Chen, 2010).

\subsection{Perceived Quality}

Persepsi terhadap atribut-atribut kualitas akan mempengaruhi keinginan melakukan kunjngan sangat kompleks misalnya saja, merek (Ling dan Li, 2010: 15-47), 
kemudahan mencari informasi destinasi, kualitas makanan, layanan, akomodasi, fasilitas, hospitality, dan harga-nilai. Kecuali ada faktor lain yaitu kualitas layanan transportasi, keamanan dan keandalan, kualitas guide dan layanan perjalanan, kualitas pantai dan lingkungan, kualitas air, kualitas operasi wisata (petunjuk dan paket perjalanan) (Yuksel, 2009: 715-733).

Persepsi kualitas yang dimiliki konsumen, semakin tinggi kecenderungan yang Tjiptono (2012) menyatakan bahwa persepsi kualitas adalah penilaian konsumen terhadap keunggulan keseluruhan suatu produk atau jasa layanan ditinjau dari fungsinya secara relatif dengan produk - produk lain. persepsi akan berhubungan dengan perilaku seseorang dalam mengambil keputusan terhadap apa yang dikehendaki. Salah satu cara untuk mengetahui perilaku konsumen adalah dengan menganalisis persepsi konsumen terhadap produk. Dengan persepsi konsumen kita dapat mengetahui hal-hal apa saja yang menjadi kekuatan, kelemahan, kesempatan ataupun ancaman bagi produk kita.

Hellier et al. (2003), Spais dan Vasileiou (2006) mendefinisi perceived quality sebagai penilaian konsumen secara keseluruhan terhadap atribut produk. Wisnalmawati (2005) mengindikasi bahwa faktor persepsi kualitas seperti dimensi penampilan fisik, keandalan, ketanggapan, jaminan dan empati berpengaruh terhadap niat berperilaku wisatawan.

\subsection{Behavioral Intention}

Behavioral intention mencakup pembelian kembali dan niat rekomendasi (Zeithaml dkk., 1996; Chen, 2008). Niat berperilaku (Behavioral Intention) menurut Peter and Olson (2002) adalah suatu proposisi yang mengaitkan diri seseorang dengan tindakan orang tersebut dimasa mendatang.

Ferdinand dalam Saidani dan Arifin (2012), indikator behavioral intention adalah sebagai berikut : Tertarik untuk mencari informasi lebih lanjut mengenai produk, Mempertimbangkan untuk membeli suatu produk, Tertarik untuk mencoba produk, Ingin membeli produk

\subsection{Kerangka Konseptual}

Sebagai konsep untuk menjelaskan, mengungkapkan, dan menentukan persepsi keterkaitan antara variabel-variabel yang akan diteliti, berdasarkan permasalahan maupun antara variabel yang berpijak dari berbagai teori, maka secara konseptual dapat digambarkan sebagai berikut :

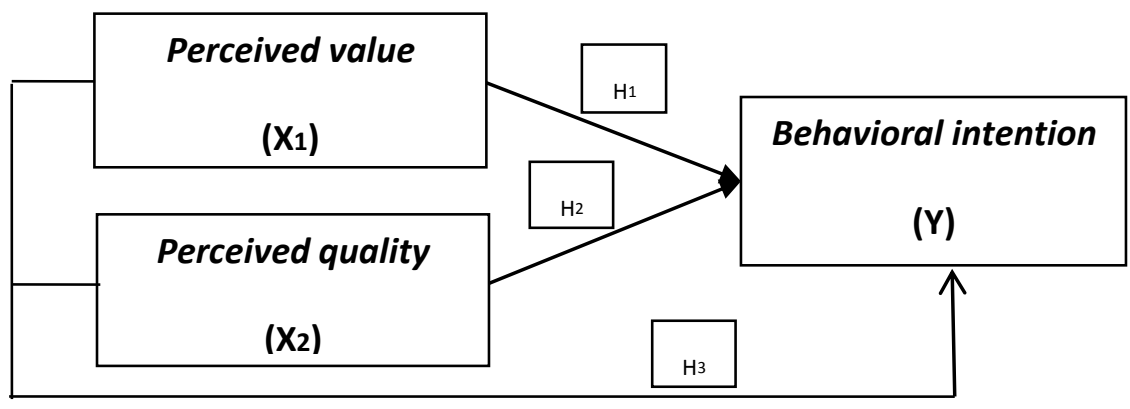

\section{Hipotesis}

Gambar 2.1. Kerangka Konseptual

H1: Perceived Value berpengaruh signifikan terhadap behavioral intention wisatawan di Taplau Padang.

H2: $\quad$ Perceived quality berpengaruh siginifikan terhadap behavioral intention wisatawan di Taplau Padang. 
H3: Perceived value dan perceived quality secara bersamaan berpengaruh siginifikan terhadap behavioral intention wisatawan di Taplau Padang.

\section{METODE PENELITIAN}

\subsection{Jenis Penelitian}

Jenis penelitian yang peneliti lakukan adalah penelitian kuantitatif deskriptif. Menurut Sugiyono (2013:7) penelitian kuantitatif deskriptif penelitian berupa angkaangka dan analisis menggunakan statistik. Penelitian ini bertujuan untuk membuktikan hipotesis penelitian. Hipotesis merupakan jawaban dari rumusan masalah yang akan diteliti. Dalam penelitian ini metode penelitian kuantitatif digunakan untuk melihat bagaimana pengaruh perceived value dan perceived qaulity terhadap behavioral intention wisatawan di Taplau Padang.

\subsection{Populasi dan Sampel}

Populasi dalam penelitian ini adalah wisatawan domestik yang berkunjung di Taplau Padang, yang jumlah populasinya tidak diketahui. Pengambilan sampel penelitian ini menggunakan teorinya Sekaran (2002:252), sebaiknya ukuran sampel diantara 30 sampai 500 elemen, untuk penelitian ini sampel di ambil sebesar 30 responden dengan menggunakan non probability sampling, dengan teknik purposive sampling. Purposive sampling adalah teknik pengambilan sampel didasarkan atas ciri khusus dari sejumlah sampel yang dianggap telah mewakili populasi, Sekaran (2002:252).

\subsection{Jenis dan Sumber Data}

\subsubsection{Jenis Data}

Menurut Sugiyono, (2012:137), jenis data yang digunakan untuk mendukung penelitian ini sebagai berikut:

1. Data kuantitatif

Data kuantitatif adalah data yang berwujud angka-angka, dalam penelitian ini data kuantitatifnya seperti jumlah konsumen dan data-data lainnya yang menunjang penelitian.

\section{Data kualitatif}

Data kualitatif adalah data yang berhubungan dengan kategori, karakteristik berwujud pertanyaan atau berupa kata-kata. Adapun data kualitatif dalam penelitian ini adalah tentang gambaran umum objek yang diteliti dengan data pengisian angket yang belum diangkakan.

\subsubsection{Sumber Data}

Menurut Sugiyono (2012:137), sumber data yang digunakan untuk mendukung penelitian ini sebagai berikut:

1. Data Primer

Data primer, yaitu data yang diperoleh langsung dari lapangan melalui penyebaran angket kepada responden untuk mengetahui tanggapan konsumen terhadap objek wisata Taplau Padang yang dapat dilihat dari perceived value dan perceived quality. Jawaban responden dihimpun dan direkapitulasi untuk kemudian diolah.

2. Data Sekunder 
Data sekunder, yaitu data yang diperoleh melalui studi kepustakaan yang relevan dengan bidang pemasaran khususnya jasa, seperti buku, jurnal, majalah, dari internet atau website yang menunjang penelitian ini.

\subsection{Teknik Pengumpulan Data}

Teknik Pengumpulan data yang dilakukan dalam penelitian ini yaitu dengan teknik observasi, angket, dan kepustakaan.

\subsection{Teknik Analisis Data}

Teknik analisa data yang digunakan dalam penelitian ini adalah analisis deskriptif, uji validitas, uji reliabilitas, analisis regresi berganda, uji t, uji $\mathrm{F}$ dan uji koefisien determinasi $\mathrm{R}^{2}$.

\section{PEMBAHASAN}

\subsection{Uji Regresi Linear Berganda}

Untuk menentukan nilai variabel X terhadap Y, Perceived Value dan Perceived Quality terhadap Behavioral Intention di Taplau Padang, maka di uji dengan menggunakan persamaan regresi linier berganda dengan menggunakan SPSS for Windows versi 24 yang dikemukakan pada Tabel 4.1 berikut ini.

Tabel 4.1 Hasil Analisis Data Untuk Persamaan Regresi Linier Berganda

\begin{tabular}{|c|c|c|c|c|c|c|}
\hline \multicolumn{7}{|c|}{ Coefficients $^{\mathrm{a}}$} \\
\hline \multirow{2}{*}{\multicolumn{2}{|c|}{ Model }} & \multicolumn{2}{|c|}{ Unstandardized Coefficients } & \multirow{2}{*}{$\begin{array}{c}\begin{array}{c}\text { Standardized } \\
\text { Coefficients }\end{array} \\
\text { Beta } \\
\end{array}$} & \multirow[t]{2}{*}{$\mathrm{T}$} & \multirow[t]{2}{*}{ Sig. } \\
\hline & & B & Std. Error & & & \\
\hline \multirow[t]{3}{*}{1} & (Constant) & 5,255 & 3,877 & & 1,356 & , 186 \\
\hline & Perceived Value & 751 & 208 &, 567 & 3,608 & 001 \\
\hline & Perceived_Quality & ,233 &, 123 & ,299 & 1,902 &, 068 \\
\hline
\end{tabular}

Sumber : Hasil Pengolahan Data SPSS versi 24 for Windows, Tahun 2017

Berdasarkan Tabel 4.1 maka ringkasan hasil pengujian dapat diformulasi dengan Persamaan Regresi Linier Berganda sebagai berikut :

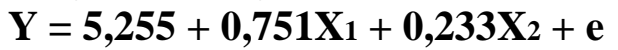

Persamaan Regresi Linier Berganda diatas dapat dijelaskan sebagai berikut :

1. Nilai Constanta 5,255 artinya jika nilai Perceived Value dan Perceived Quality (konstan) maka Behavioral Intention di Taplau Padang sudah ada sebesar 5,255 satuan.

2. Perceived Value $=0,751$ hal ini menunjukan bahwa setiap peningkatan 1 (satuan) Perceived Value dengan Perceived Quality (konstan) maka terjadi peningkatan Behavioral Intention di Taplau Padang sebesar 0,751.

3. Perceived Quality $=0,233$ hal ini menunjukan bahwa setiap peningkatan satu (satuan) Perceived Quality Pantai Padang dengan Perceived Value (konstan) maka terjadi peningkatan Behavioral Intention di Taplau Padang sebesar 0,233.

\subsection{Uji t (Parsial)}

Uji t dilakukan untuk menguji masing - masing variabel atau secara parsial variabel Independent Perceived Value dan Perceived Quality terhadap Behavioral Intention di Taplau Padang, maka dilakukan pengujian statistik dengan melakukan Uji t. Berdasarkan hasil pengujian yang dilakukan maka ditemukan hasil seperti yang terlihat pada Tabel 1.2 berikut ini : 
Polibisnis, Volume 9 No. 2 Oktober 2017

Tabel 4.2. Hasil Analisis Data Uji t

\begin{tabular}{|c|c|c|c|c|c|c|}
\hline \multicolumn{7}{|c|}{ Coefficients $^{\mathrm{a}}$} \\
\hline \multirow{2}{*}{\multicolumn{2}{|c|}{ Model }} & \multicolumn{2}{|c|}{ Unstandardized Coefficients } & Standardized & T & Sig. \\
\hline & & B & Std. Error & Beta & & \\
\hline \multirow[t]{3}{*}{1} & (Constant) & 5,255 & 3,877 & & 1,356 & ,186 \\
\hline & Perceived_Value & ,751 & ,208 &, 567 & 3,608 &, 001 \\
\hline & Perceived_Quality & ,233 & ,123 & ,299 & 1,902 &, 068 \\
\hline
\end{tabular}

a. Dependent Variable: Behavioral Intention

Sumber : Hasil Pengolahan Data SPSS versi 24 for Windows, Tahun 2017

Berdasarkan hasil pengujian secara uji t (Uji parsial) mengenai distribusi masingmasing variabel Perceived Value dan Perceived Quality terhadap Behavioral Intention di Taplau Padang dapat diuraikan sebagai berikut :

1. Hasil uji t untuk distribusi Perceived Value terhadap Behavioral Intention. Hasil Uji $\mathrm{t}$ ini menghasilkan $\mathrm{t}_{\text {hitung } 3,608>\mathrm{t}_{\text {tabel }} 1,699 \text { dengan nilai signifikansi } 0,001<\text { level }}$ of significant 0,05 maka hasil penelitian berdistribusi dengan hasil positif berarti hipotesis Ha diterima dan Ho ditolak untuk menyatakan bahwa Perceived Value berpengaruh signifikan terhadap Behavioral Intention di Taplau Padang.

2. Hasil uji t untuk distribusi Perceived Quality terhadap Behavioral Intention menghasilkan $\mathrm{t}_{\text {hitung }} 1,902>\mathrm{t}$ tabel 1,699 dengan nilai signifikansi $0,068<$ level of significant 0,05 maka hasil penelitian berdistribusi dengan hasil positif. Hasil Uji t ini berarti hipotesis Ha ditolak dan Ho diterima untuk menyatakan bahwa Perceived Quality tidak berpengaruh signifikan terhadap Behavioral Intention di Taplau Padang. Sebagaimana yang dikemukan oleh Sugiyono (2012:251) bahwa pengaruh masing-masng variabel bebas terhadap variabel terikat secara parsial dengan tingkat kesalahan $5 \%$.

\subsection{Uji F (Simultan)}

Hasil Uji F dilakukan untuk mengetahui pengaruh Perceived Value dan Perceived Quality terhadap Behavioral Intention di Taplau Padang secara Simultan dapat dilihat pada Tabel 4.3 berikut ini ;

Tabel 4.3. Hasil Analisis Data Uji F ANOVA $^{\mathrm{a}}$

\begin{tabular}{llr|r|r|r|r} 
& & Sum of Squares & df & Mean Square & F & Sig. \\
\hline 1 & Regression & 443,066 & 2 & 221,533 & 24,154 &, $000^{\circ}$ \\
\cline { 2 - 7 } & Residual & 247,634 & 27 & 9,172 & & \\
\cline { 2 - 7 } & Total & 690,700 & 29 & & & \\
\hline
\end{tabular}

a. Dependent Variable: Behavioral_Intention

b. Predictors: (Constant), Perceived_Quality, Perceived_Value

Sumber : Hasil Pengolahan Data SPSS versi 24 for Windows, Tahun 2017

Hasil uji F untuk menguji variabel secara simultan terhadap Y, Perceived Value dan Perceived Quality secara bersama terhadap Behavioral Intention seperti yang dikemukakan pada Tabel 4.3 menghasilkan $\mathrm{F}_{\text {hitung }} 24,154>\mathrm{F}_{\text {tabel }}$ 4,20 dengan nilai signifikansi 0,000 <level of significant 0,05 . Maka hasil Uji F ini berarti hipotesis Ho ditolak dan Ha diterima untuk menyatakan bahwa Perceived Value dan Perceived 
Quality secara bersamaan berpengaruh signifikan terhadap Behavioral Intention di Taplau Padang.

\subsection{Koefisien Determinasi $\left(\mathbf{R}^{2}\right)$}

Hasil Pengujian koefisien determinasi untuk mengetahui pengaruh Perceived Value dan Perceived Quality terhadap Behavioral Intention di Taplau Padang dapat dilihat pada Tabel 4.4 berikut ini :

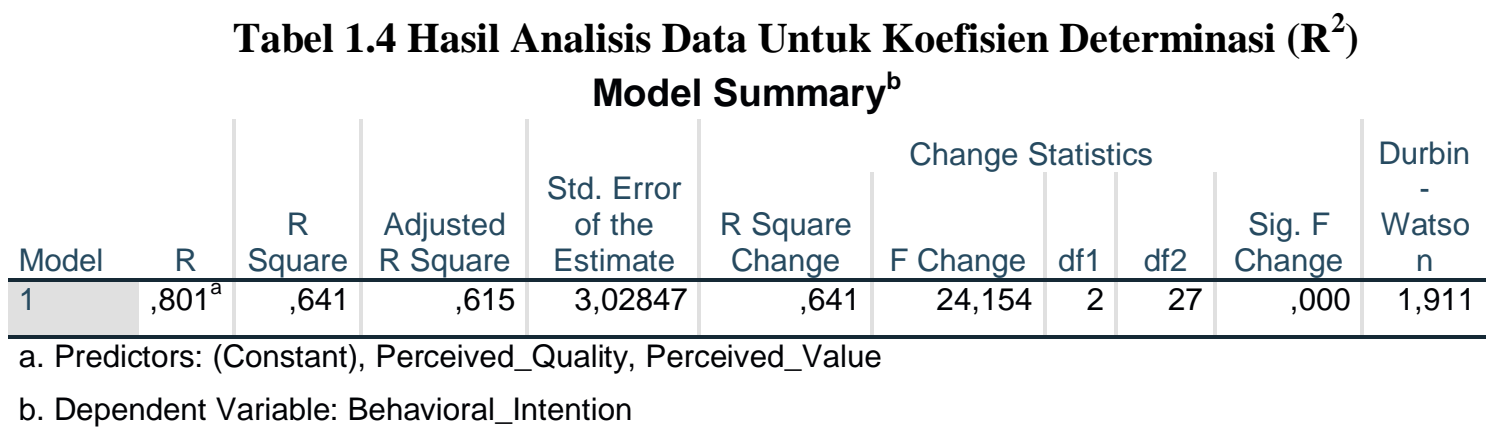

Sumber : Hasil Pengolahan Data SPSS versi 24 for Windows, Tahun 2017

Hasil Pengujian koefisien determinasi untuk menentukan kontribusi variabel $\mathrm{X}$ terhadap variabel Y Perceived Value dan Perceived Quality secara bersamaan terhadap Behavioral Intention di Taplau Padang yang dikemukakan pada Tabel 4.4 menghasilkan nilai koefisien determinasi pada kolom Adjusted $R$ Square 0,615. Maksudnya adalah besarnya kontribusi pengaruh Perceived Value dan Perceived Quality terhadap Behavioral Intention wisatawan di Taplau Padang sebesar 61,5\% dan sisanya sebesar $38,5 \%$ dipengaruhi oleh variabel selain dari pengaruh Perceived Value dan Perceived Quality.

\subsection{Pembahasan Hasil Penelitian}

Berdasarkan analisis data mengenai pengaruh Perceived Value dan Perceived Quality secara parsial dan secara bersamaan terhadap terhadap Behavioral Intention di Taplau Padang, Maka pembahasan hasilnya adalah sebagai berikut :

1. Pengaruh Perceived Value terhadap Behavioral Intention.

Hasil uji t untuk distribusi Perceived Value terhadap Behavioral Intention. Hasil Uji t ini menghasilkan $\mathrm{t}_{\text {hitung }} 3,608>\mathrm{t}_{\text {tabel }}$ 1,699 dengan nilai signifikansi 0,001 < level of significant 0,05 maka hasil penelitian berdistribusi dengan hasil positif berarti hipotesis Ha diterima dan Ho ditolak untuk menyatakan bahwa Perceived Value berpengaruh signifikan terhadap Behavioral Intention di Taplau Padang. Secara parsial Perceived Value berpengaruh terhadap Behavioral Intention di Taplau Padang, karena memperoleh signifikan lebih kecil dari 0,05. Hal ini menunjukan bahwa dengan adanya Perceived Value yang baik oleh wisatawan, maka hal ini akan meningkatkan Behavioral Intention wisatawan untuk berkunjung di Taplau Padang.

2. Pengaruh Perceived Quality terhadap Behavioral Intention. Hasil uji t untuk distribusi Perceived Quality terhadap Behavioral Intention menghasilkan $\mathrm{t}_{\text {hitung }}$ 1,902 $>\mathrm{t}_{\text {tabel }}$ 1,699 dengan nilai signifikansi $0,068<$ level of significant 0,05 maka hasil penelitian berdistribusi dengan hasil positif. Hasil Uji t 
ini berarti hipotesis Ha ditolak dan Ho diterima untuk menyatakan bahwa Perceived Quality tidak berpengaruh signifikan terhadap Behavioral Intention wisatawan di Taplau Padang.

Secara parsial Perceived Quality tidak berpengaruh signifikan terhadap Behavioral Intention wisatawan di Taplau Padang, karena nilai signifikannya lebih besar dari 0,05. Hal ini menunjukan bahwa Perceived Quality oleh wisatawan tidak akan mempengaruhi Behavioral Intention wisatawan untuk berkunjung di Taplau Padang.

3. Pengaruh Perceived Value dan Perceived Quality secara bersamaan terhadap terhadap Behavioral Intention di Taplau Padang,.

Hasil uji F untuk pengaruh Perceived Value dan Perceived Quality secara parsial dan secara bersamaan terhadap terhadap Behavioral Intention wisatawan di Taplau Padang yang terdapat pada Tabel 4.3, terlihat bahwa $\mathrm{F}_{\text {hitung }} 24,154>\mathrm{F}_{\text {tabel }} 4,20$ dengan nilai signifikansi 0,000 <level of significant 0,05 . Maka hasil Uji F ini berarti hipotesis Ho ditolak dan Ha diterima untuk menyatakan bahwa perceived value dan perceived quality secara bersamaan berpengaruh signifikan terhadap Behavioral Intention wisatawan di Taplau Padang. Dan hasil pengujian koefisien determinasi, memberikan kontribusi pengaruh perceived value dan perceived quality terhadap behavioral intention sebesar 0,615, atau 61,5\% dan sisanya sebesar 38,5\% dijelaskan oleh variabel selain dari pengaruh perceived value dan perceived quality.

\section{SIMPULAN DAN SARAN}

\subsection{Simpulan}

1. Variabel perceived value berpengaruh signifikan terhadap behavioral intention wisatawan di Taplau Padang dengan nilai signifikan sebesar 0,001 $<0,05$.

2. Variabel perceived quality tidak berpengaruh signifikan terhadap behavioral intention wisatawan di Taplau Padang, dengan nilai signifikan sebesar 0,068 > 0,05 .

3. Variabel perceived value dan perceived quality berpengaruh secara simultan terhadap behavioral intention wisatawan di Taplau Padang, dengan nilai signifikan $0,000<0,05$, sedangkan nilai adjusted $R$ Square sebesar 0,359. Hal ini berarti kemampuan variabel bebas dalam menjelaskan variabel terikat adalah sebesar $61,5 \%$ sisanya $38,5 \%$ dipengaruhi oleh variabel lain yang tidak dibahas dalam penelitian.

\subsection{Saran}

1) Para pemangku kepentingan untuk lebih menjadikan Taplau Padang sebagai tempat yang menarik untuk dikunjungi sehingga para wisatawan memunculkan perasaan senang bagi wisatawan ketika berkunjung di Taplau Padang. Di samping itu perlu juga untuk memberdayakan masyarakat sekitar Taplau Padang untuk membangun hubungan yang baik dan ramah bagi para wisatawan.

2) Keindahan pantai padang perlu di tata dan dipertahankan sehingga memimbulkan niat para wisatawan untuk berkunjung. Dan keindahan pantai tersebut dapat memunculkan informasi yang baik wisatawan untuk memberi rekomendasi bagi keluarga, teman dan pihak lain untuk datang berkunjung ke Taplau Padang.

3) Bagi penelitian lain untuk dapat menambah sampel yang diteliti dan variabel lain yang sesuai dengan kondisinya pada saat akan melakukan penelitian. 
Polibisnis, Volume 9 No.2 Oktober 2017

\section{DAFTAR PUSTAKA}

Bajs, I. P. (2013). Tourist Perceived value , Relationship to Satisfaction, and Behavioral Intentions: The Example of the Croatian Tourist Destination Dubrovnik. Journal of Travel Research, 54(1), 122-134. doi:10.1177/0047287513513158.

Chen, C.-F., \& Chen, F.-S. (2010). Experience quality, perceived value , satisfaction and Behavioral Intentions for heritage tourists. Tourism Management, 31(1), 2935. doi:10.1016/j.tourman.2009.02.008

Chen, C.F. (2008). Investigating structural relationships between service quality, perceived value, satisfaction, and behavioral intentions for air passengers: Evidence from Taiwan. Transport Resources Part A, 42(4), 709-717.

Chi, Hsinkuang, Yeh, Huery Ren \& Tsai, Yi Ching. 2011. The Influences of Perceived Value on Consumer Purchase Intention: The Moderating Effect of Advertising Endorser. Journal of International Management-jims journal.

Ernawati dan Untung Sriwidodo. 2012. "Faktor yang Berpengaruh terhadap Kepuasan Konsumen dan Behavioral Intention dengan Perceived Value Sebagai Variabel Moderasi”. Jurnal Ekonomi dan Kewirausahaan, Vol. 12 No.1, pp 47-57.

Hellier, P. K., G. M. Geursen, R. A. Carr \& J. A. Rickard. 2003. "Customer

Repurchase Intention: A general structural equation model". European Journal of Marketing, Vol. 37, No. 11/12, pp.1762-1800.

Kotler, Philip dan Kevin Lane Keller. 2009. Manjaemen Pemasaran. Diterjemahkan oleh Bob Sabran M.M. Edisi Ketiga Belas. Jilid 1. Jakarta Erlangga.

Ling--Feng H and Li-Hsin W. 2010. The Performance Evaluation Model for Tourism Industry Selection Deparment of Technology Management. Chun Hua University. $15-47$.

Peter, J. P., \& Olson, J. C. (2002). Consumer Behavior and Marketing Strategy (6 ed.): McGraw-Hill Irwin.

Saidani, Basrah dan Samsul Arifin. 2012. "Pengaruh Kualitas Produk dan Kualitas pelayanan terhadap Kepuasan Konsumen dan Minat Beli Pada Ranch Market”. Jurnal Riset Manajemen Sains Indonesia, Vol. 3 No. 1, pp 1-22.

Sekaran, Umar. 2002. Research Methods For Business Metodologi Penelitian Untuk Bisnis. Edisi 4, Buku 1. Jakarta: Salemba Empat.

Spais, G. S. \& K. Vasileiou. 2006. "Path Modeling The Antecedent Factors To Consumer Repurchase Intentions For Advanced Technological Food Products: Some Correlations Between Selected Factor Variables". Journal of Business Case Studies, Vol. 2,No. 2, Second Quarter.

Subagio, Hartono dan Saputra Robin, "Pengaruh Perceived Service Quality, Perceived Value, Satisfaction, dan Image terhadap Customer Loyalti (Studi kasus Garuda Indonesia)". Jurnal Manajemen Pemasaran, Vol. 7, No. 1, April 2012, ISSN 1907 235X, pp. 42-45.

Sugiyono. 2012. Metode Penelitian Pendidikan Kuantitatif, Kualitatif dan R\&D. Bandung: CV. Alfabeta.

Sugiyono. 2013. Metode Penelitian Manajemen. Bandung: CV. Alfabeta.

Suvi, Kurki, et al. "Customer Value In Electronic Retailing: A Laboratory Experiment In Buying Cloth. www.ecf.fi.

Fandy Tjiptono, (2012). Pemasaran Jasa, Malang: Bayumedia Publishing 
Polibisnis, Volume 9 No. 2 Oktober 2017

Wisnalmawati. 2005. "Pengaruh Persepsi Dimensi Kualitas Layanan terhadap Niat Pembelian Ulang”. Jurnal Ekonomi \& Bisnis, No. 3, Jilid 10 2005, PP. 153165.

Yuksel, Atila, 2009. The Quest for Quality and Competitiveness on Tourism. Sheffield Hallam University, UK. Pp 715-733

Zeithaml, V. A., Berry, L. L., \& Parasurman, A. (1996). The behavioral consequences of service quality. Journal of Marketing, 60(2)), pp 31-46. 